J O U R N A L O F French and Francophone Philosophy
REVUE DE LA

philosophie française et de langue française

\title{
Emerging from the Depths \\ On the Intensive Creativity of Historical Events
}

\section{Craig Lundy}

Journal of French and Francophone Philosophy - Revue de la philosophie française et de langue française, Vol XVIII, No 1 (2008-2010) pp. 67-85.

\author{
Vol XVIII, No 1 (2008-2010) \\ ISSN 1936-6280 (print) \\ ISSN 2155-1162 (online) \\ DOI $10.5195 /$ jffp. 2010.171 \\ http://www.jffp.org
}

\section{(c) EY-NC-ND}

This work is licensed under a Creative Commons Attribution-Noncommercial-No Derivative Works 3.0 United States License.

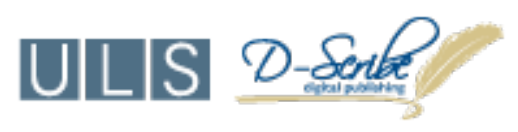

This journal is operated by the University Library System of the University of Pittsburgh as part of its D-Scribe Digital Publishing Program, and is co-sponsored by the University of Pittsburgh Press 


\title{
Emerging from the Depths
}

\section{On the Intensive Creativity of Historical Events}

\author{
Craig Lundy \\ Middlesex University
}

\section{Introduction}

In his collection of essays On History, Fernand Braudel offers us a moving image for the nature of historical events. Commenting in reference to a display of fireflies he says, "their pale lights glowed, went out, shone again, all without piercing the night with any true illumination. So it is with events; beyond their glow, darkness prevails." ${ }^{1}$ Although it is the glow of an event that catches our eye and fascinates us, Braudel argues that this is only the initial (and at times most superficial) element of historical understanding. Such events emerge from an impenetrable milieu - a darkness or contingency - and this black night must be taken seriously. This means that even the brightest of stars must be related to the indeterminate realm that they light up. Two methods for achieving this offer themselves. On the one hand, we could carve out the historical event from its field of indeterminacy by graphing its flight from above; we could, in other words, come to know the coordinates of the event. But on the other hand, we could follow the firefly as its weaves through the night by placing ourselves within its line of flight; we could, according to this other method, come to know the life of an event by living with it.

When developing their theory of the event, Deleuze and Guattari seize upon a similar conceptual distinction. As they state:

[T]here are two ways of considering the event. One consists in going over the course of the event, in recording its effectuation in history, its conditioning and deterioration in history. But the other consists in reassembling the event, installing oneself in it as in a becoming, becoming young again and aging in it, both at the same time, going through all its components or singularities. $^{2}$ 
Much like Braudel, this passage describes how Deleuze and Guattari seek to get inside the environs of an event in order to gain an understanding of it that goes deeper than firefly watching. This theory of the event, however, can be directly traced to Deleuze's reading of Charles Péguy's work Clio. ${ }^{3}$ In the two versions of this essay, Péguy illustrates a theme that is common to all of his historical commentaries: factual details, on their own, are insufficient for understanding an historical event; what is also needed is an appreciation of the spirit of an age, people and/or movement - its mystique. ${ }^{4}$ But as Deleuze and Guattari echo the insights of Péguy and Braudel, a curious transformation takes place. Whereas for Péguy and Braudel the reassembling of (and placing oneself within) the event was a way of practicing and understanding history, for Deleuze and Guattari this alternative method is directly positioned against history and the historical. How then has this occurred?

In this paper I will show how there are two different forms of history at work in Deleuzian ontology: one which could be characterised as opposed to becoming, and another which is in productive union with it. Drawing from the intimations of Braudel and Péguy above, the location of this alternative notion of history will be beyond the superficial glow and within the event it will occur in the depths. In its colloquial context, depth is often used to indicate the past and history. For example, to understand a present situation "in depth" is in many respects (though not all) to have experience, familiarity or knowledge of its past. However, as we will see, it is equally plausible to consider Deleuze's notion of intensive-depth as compatible with a kind of history.

To do so, this paper will reunite Deleuze's concept of intensive-depth with several of its most significant sources: Braudel, Péguy and one of Deleuze's most important ontological touchstones, Henri Bergson. By emphasising how these other thinkers develop a theory of intensive production that is (in part) historical in nature, Deleuze's work will be reappraised to see what it might have to offer a philosophy of historical creativity - that is, a form of history that is not static and fixating, but rather a dynamic force of creativity. But if this attempt is to be successful, two questions must be adequately addressed: can history be intensive, and if so, is the placing of ourselves into the depths of the past, so that we may move with it as it becomes, a viable ontology and methodology of history? In responding to these questions, this paper will not only carry out a reconciliation of history with becoming in the work of Deleuze; more importantly, it will indicate how Deleuze can provide a significant contribution to the lineage of thinkers who believe in a truly creative historical ontology. 


\section{Historical Intensities}

Deleuze's concept of intensity, it might initially seem, would not be a prudent place to look for a philosophy of history. This is because history, as we will shortly see, is often associated by Deleuze with those things that are decidedly un-intensive. The most obvious place for history would therefore seem to be on the side of extensity rather than intensity. While this is no doubt true, it must nevertheless be acknowledged that this is not all that history can be or become; aside from the figure of extensive history, there is another form of history in Deleuze that can be legitimately described as intensive. But before we can challenge the initial assumption and limitations of extensive history, we must first set out what Deleuze means by intensity. In the process, possibilities for an intensive concept of history (and vice versa) will begin to emerge.

Taking up Kant's brief discussion of intensive magnitudes in the "Anticipations of Perception," ${ }^{5}$ Deleuze distinguishes between two forms of quantity: intensive and extensive. Although intensive quantities can be measured and ordered, they differ from extensive quantities in that they do not adhere to a whole-part metric that would allow them to be manipulated by procedures such as addition. For example, if one body of water measuring $10^{\circ} \mathrm{C}$ is added to another body of water measuring $20^{\circ} \mathrm{C}$, the two do not add up to $30^{\circ} \mathrm{C}$. Likewise, the sensation of my body moving at $20 \mathrm{kph}$ is not reducible to a summation of the sensations my body experiences moving at $15 \mathrm{kph}$ and $5 \mathrm{kph}$, for if it were so then I could claim that I know what it is like to move at the speed of light (and beyond). We of course need not limit ourselves to examples of temperature or speed - psychological experiences such as love and anger are as equally suitable. For example, one cannot add-up lesser values of love in order to produce a higher order of love (God's love is of a different order to ours, no matter how many of us there are, or how developed we become). In each case, the quantities at issue are intensive, and as such are incapable of being divided without effectuating a change in its nature. ${ }^{6}$

The inability of intensive quantities to be divided without changing in kind means that each intensity exists as what Bergson, drawing from Riemann, referred to as a continuous multiplicity. Deleuze makes this debt clear when he modifies Bergson's two multiplicities of continuous and discrete (or heterogeneous and homogeneous) into implicit and explicit: "We must henceforth distinguish between two types of multiplicities [...]: implicit as opposed to explicit multiplicities; those whose metric varies with division and those which carry the invariable principle of their metric." ${ }^{7}$ As this passage shows us, an intensive magnitude is a heterogeneous or implicit multiplicity that cannot be divided without effectuating a change in nature. This means that every heterogeneous multiplicity is a singular-composite: singular insofar as it is indivisible (without changing what it is into 
something else), yet a composite of differentiated elements. Another way of putting this would be to say that each heterogeneous multiplicity is an ordered whole of difference. But as Bergson's ontology continues, each of these ordered wholes can themselves be related to other orders that differ precisely in the degree of their difference - the different ways in which each order makes a singularity of difference. Intensive quantities obey the same ontology. On the one hand, every intensity is ordered as a continuous heterogeneity (as opposed to discrete homogeneities that give themselves to be added and divided without prejudice). But on the other hand, each of these intensities is itself within an order or continuum of difference, hierarchized according to ascending and descending degrees. ${ }^{8}$ Thus every intensity is an ordered whole within an order, and their demarcation from one another determines at once both their internal heterogeneity (endoconsistency) as well as the external relations of that continuous heterogeneity to another (exoconsistency). Difference can then be said to occur both at every level and between every level in precisely that way in which they differ.'

As the above presentation of intensity suggests, an intensity is defined by the singular nature of its difference. The identity of an intensity is thus produced by difference. This theme of constitutive difference is of course a central concern throughout Difference and Repetition. It is, however, Deleuze's final treatment of difference that is arguably of most significance to a philosophy of history. In this concluding chapter, Deleuze's primary concern is not so much with the difference between the past, present and future (the topic of chapter 2), but rather "differences of level, temperature, pressure, tensions, potential, difference of intensity." ${ }^{10}$ It is these differences that are the stuff of history; if history is concerned with the relations between past, present and future, it is because these relations are a necessary part of the intensive differences by which reality is produced. This means that while the philosophy of history is no doubt dependent upon a philosophy of time, an investigation of the latter cannot stand for the former, since history is not reducible to time. ${ }^{11}$ Looking ahead to the direction Deleuze will take his philosophy of history with Guattari, it is not difficult to see that theories of space will be as equally important as time: Deleuze and Guattari's nomadology, for example, will be opposed to traditional history first and foremost on spatial and topological grounds; their geophilosophy, to continue, will draw its inspiration from a history that is decidedly geographical (Braudel's geohistory ${ }^{12}$ ). These future projects, however, are dependent upon Deleuze's conception of intensity-as-difference - a conception that complements the earlier philosophy of time in Difference and Repetition by specifically addressing the issue of space.

Crucial to this differential philosophy of space is the argument that the world cannot be finished or exact, for if it was then it would either be dead or cease to exist. ${ }^{13}$ The world is therefore in extrapolation: a process of 
continual emergence that is constantly undergoing adjustment and readjustment - negotiation - of various differences in intensity. These differences in intensity must in turn be conditioned and correlated if we are to make sense of the newly emerged. However, in the act of 'making sense of' difference, difference becomes reified and stratified; difference becomes fixed, and as such emptied of its difference. This means that while an intensive difference is productive of extensive reality, in so doing it abolishes itself as a difference. More precisely, intensity-as-difference covers over, cancels out, and/or extends itself into an extensity or quality that in one and the same stroke identifies the existence of the intensive difference while effacing it: intensity, in other words, is suicidal. As Deleuze says:

Intensity is difference, but this difference tends to deny or to cancel itself out in extensity and underneath quality. It is true that qualities are signs which flash across the interval of a difference. In so doing, however, they measure the time of an equalization - in other words, the time taken by the difference to cancel itself out in the extensity in which it is distributed. ${ }^{14}$

The paradoxical nature of intensity is thus as follows: on the one hand, the intensive is that which resists being sensed "independently of the qualities which cover it and the extensity in which it is distributed"; but on the other hand, intensity is the only thing which can be sensed, "since it is what gives to be sensed, and defines the proper limits of sensibility." ${ }^{15}$ This means that although intensity destroys itself, it only does so as a result of its own productive and metamorphic power. Put otherwise, the explication of an intensive force is not so much a dissipation as it is a creative explosion.

Deleuze emphasises this distinction between a dissipation of force and an affirmative explication of it in his discussion of thermodynamics. As he notes, despite its affinity with process and change, classical thermodynamics was overly concerned with the eventual equalisation of that change. ${ }^{16}$ In so doing, classical thermodynamics turned away from an appreciation of the intensive processes that produce the states of equalisation. Today's far-fromequilibrium thermodynamics seeks to correct this oversight. As Manuel DeLanda explains it: "[W]hile equilibrium thermodynamics focuses on what happens once the intensive differences have been cancelled, far-fromequilibrium thermodynamics studies systems that are continuously traversed by a strong flow of energy or matter, a flow which does not allow the differences in intensity to be cancelled, that is, a flow that maintains these differences and keeps them from cancelling themselves out." ${ }^{17}$ Farfrom-equilibrium thermodynamics thus does not efface intensities by dissipating/equalising their force, but rather pushes them towards future productivities by keeping them open. Employing alternative Deleuzian terms, one could say that far-from-equilibrium dynamics does not allow processes of becoming to coalesce into fully static and explicated beings. 
By invoking the ontological dualism of becoming and being, the question of history's place in this schema is brought into relief. As is well documented, Deleuze repeatedly opposes becoming to history. To give just one example:

What history grasps in an event is the way it's actualised in particular circumstances; the event's becoming is beyond the scope of history [...]. Becoming isn't part of history; history amounts to only the set of preconditions, however recent, that one leaves behind in order to 'become', that is, to create something new. ${ }^{18}$

In Difference and Repetition, this notion of history is specifically attacked as historicism and contrasted with the virtual structure of the Idea. ${ }^{19}$ History understood as such is thus opposed to the unknown and the creation of the new, for it is designated the task of capturing and representing what is created in an order of causal-linear succession.

But while this reading of history in Deleuze is more or less undeniable, the claim of this paper is that it does not by itself stand for a Deleuzian philosophy of history. According to the above topology, histories are extensive series that spiral away on the surface from those intensive breaks that cause a change in kind. For instance, the historical series of "before the war," "after the revolution," "post-colonial history" or "prehistoric times" are all extensive series that proceed from an intensive moment/movement of becoming: after the intensive creations of May '68 are captured, to take one example, we are presented with various extensive histories that spiral from and towards that point, making sense of the revolutionary event in various ways (or perhaps even ignoring the event itself). Two questions however immediately assert themselves: (1) must this scenario always occur in a 1-2 step process, creation occurring first and capture second?; and (2) could not history already be a part of the productive process that leads to extensive historical series? Both of these questions can be answered by showing how history is itself constitutive, and dynamically so.

This can be achieved by returning to our discussion of thermodynamics. The issue of thermodynamics is crucial, for it is the science that is arguably most concerned with asymmetrical movements - the kind of movements that are most often associated with the onward march of history. ${ }^{20}$ More specifically, according to Deleuze, thermodynamics is concerned with the asymmetric movement from the intensive to the extensive. Thermodynamics thus addresses the serial movement from depth to surface, as opposed to those sciences that are only concerned with analysing surface series of extensity. The problem for classical thermodynamics, to recap our discussion above, was that in pursing the equalisation of intensive processes, it promoted an ontology in which a final future state acted as an inescapable attractor what Bergson would call radical finalism. ${ }^{21}$ With equalisation as its raison 
d'être, classical thermodynamics was only capable of proving its own presuppositions. This in turn discredited the effectivity of the process in realising the final state - the road travelled rendered inconsequential. In contrast to this, far-from-equilibrium thermodynamics attempts to avert this equalisation and thus evade a radical finalism. As a result, the productivity of intensity remains open and active, undecided and contingent. This means that the line drawn from depth to surface is not an ineffectual shadow of the final state, but is truly productive of what it is that comes about. But what are these various paths to equilibria if not differentiated histories by which a thermodynamic force moves towards explication? As DeLanda puts it when distinguishing classical from far-from-equilibrium thermodynamics:

[I]nstead of the single global equilibrium of the classical theory we now have multiple equilibria, which means that history matters. While with a single possible outcome the different paths followed by systems on their way there can be ignored, with multiple possible outcomes the details of the history followed matter. 22

When the result is known in advance, who cares for history? Such a history is a mere formality - an extensive series that always leads to and issues from the already known. But in far-from-equilibrium thermodynamics history can no longer be taken for granted; history becomes constitutive at precisely that point where the future becomes open. When the future is genuinely unknown, it matters a great deal whether we turn left of right at the next junction, for these details will contour the field of possibility, creating and closing alternatives. While it is not my intention here to suggest a vulgar tree diagram of history, it must nevertheless be acknowledged that in any particular instance certain outcomes are more likely (physically attractive) than others. This empirical fact cannot be denied. But as much modern science testifies, attractors need not be radically mechanistic or deterministic: while there may be basins of attraction, this does not preclude their emergent alteration. The critical point is, however, the following: the contingencies of historical encounters are in part responsible for the movements from one phase-space or basin of attraction to another. Thus to allow for the contingency of the event is to affirm the historical processes of production, not to deny them. Unlike the historical series of extensive surfaces, the historical processes of production are utterly different in kind, for they are indeed productive of historical extensities.

It must be admitted, however, that this analysis of productive intensity has yet to establish a clear link with what I am referring to as the historical processes of production. To properly achieve this we must now look more closely at what Deleuze means by depth. 


\section{In the Depths of History}

As noted above, extensive quantities can be divided and added together due to their adherence to whole-part relations. This aspect is, however, more than just a simple capability: extensive quantities are themselves only given insofar as they express a whole-part relation. For example, what is high is determined by its relation to what is low, what is right is determined by its relation to what is left, and so on. But as Deleuze points out, surely "right" must be more than just "to the right"; it must be more than just an inverted "left," for if it were not then the two would fail to genuinely differ in kind. Therefore, if right is to maintain a difference in kind to left, then the extensity of right within an external relation must be predicated upon the intensive determination of right within itself. This is to say that the measure of an intensive quantity is always given according to its own metric. Intensities submit to no standard, for they are indeed that which produces standards - standards are made of them. Insofar as the measure of an intensity always comes from within, what is being measured is none other than the depth of that intensity. It is therefore in depth and through depth that the productive processes of intensities take place. As Deleuze says, while an extensive quantity measures distance, length or size, these determinations themselves "flow from a 'deeper' instance - depth itself, which is not an extension but a pure implex." ${ }^{23}$ And again:

Extensity does not develop or appear without presenting a left and a right, a high and a low, an above and a below, which are like the dissymmetrical marks of its own origin. The relativity of these determinations, moreover, is further testimony to the absolute from which they come. Extensity as a whole comes from the depths. Depth as the (ultimate and original) heterogeneous dimension is the matrix of all extensity $[\ldots] .^{24}$

As this passage shows us, the relational marks that set out the scale or hierarchy of a series form scars that betray an originary injury - "the absolute from which they come." This absolute is depth. However, it is a heterogeneous absolute, a matrix that makes whole of a multiplicity: "The original depth [...] is indeed space as a whole, but space as an intensive quantity: the pure spatium. ${ }^{\prime 25}$ But if it is in depth that a measure of worth is given, then in order to gauge it we must delve into it; extensive assessment will not suffice, we must place ourselves within depth in order to feel its own internal pulse or rhythm.

When so put, Deleuze's intensive-depth can be seen to have much in common with the notion of productive-depth used by his conceptual forebears. Take Bergson to begin with. I have already shown how Deleuze's understanding of intensity draws from Bergson's heterogeneous multiplicity. It is, however, Bergson's heterogeneous multiplicity of duration 
in particular that is most instructive for Deleuzian depth. In solving Zeno's paradox of the footrace between Achilles and the tortoise, Bergson demonstrates that Achilles will never pass the tortoise so long as time and motion is reduced to a homogeneous plane of space. As with the trajectory of an arrow, each stride of both Achilles and the tortoise is an indivisible movement, meaning, it cannot be divided without changing it in kind. Each stride, as it were, comes from the depths of their respective durations. While these different durations can in turn be mapped onto an extensive space the ground they are racing on - this does not mean that their intensive durations can be reduced to this shared homogeneous space:

But the truth is that each of Achilles' steps is a simple indivisible act, and that, after a given number of these acts, Achilles will have passed the tortoise. The mistake of the Eleatics arises from their identification of this series of acts, each of which is of a definite kind and indivisible, with the homogeneous space which underlies them. ${ }^{26}$

When the duration of Achilles is defined by the homogeneous space he shares with the tortoise, Zeno's paradox arises - every time Achilles attempts to bridge the final gap, he must first cover half that distance. Thus as long as Achilles' stride can be extensively divided without changing it in kind (i.e. without the realisation that it is no longer Achilles who is racing), he will be unable to reach the tortoise. But if the stride of Achilles is taken as a continuous motion of duration, an indivisible intensity that is greater in magnitude than the intensive quantity of the tortoise, then Achilles will be able to take that final step to victory. Zeno knows as well as anyone that Achilles must win. He knows that while his paradox appears to hold on paper, that in the flesh Achilles will clearly streak by the tortoise. Bergson's insight is to take this distinction between the static representation of motion in homogeneous space and the vital movement of heterogeneous time in duration seriously: "Why resort to a metaphysical hypothesis, however ingenious, about the nature of space, time and motion, when immediate intuition shows us motion within duration, and duration outside space?"27 This means that to consider the race in real duration, one must draw a continuous line of heterogeneity from the depths of the past to the present moment that is emerging. It is only by doing so that we can gauge the confluence of multiple durations (e.g. Achilles', the tortoise's and ours) and thus experience the passing of time. For this reason, if time is to be vital and ongoing, it must be connected not as a discrete plane of homogeneity but as a continuous multiplicity of heterogeneity. The present moment must not be severed from the depths of the past, but made thick with it:

Let us $[\ldots]$ grasp ourselves afresh as we are, in a present which is thick, and furthermore, elastic, which we can stretch indefinitely backward by pushing the screen which masks us from ourselves farther and farther away; let us 
grasp afresh the external world as it really is, not superficially, in the present, but in depth, with the immediate past crowding upon it and imprinting upon it its impetus; let us in a word become accustomed to see all things sub specie durationis: immediately in our galvanized perception what is taut becomes relaxed, what is dormant awakens, what is dead comes to life again. ${ }^{28}$

Although it is not mentioned in the above passage, what Bergson is specifically describing here is his notion of philosophical intuition. Unlike the intellect, which concerns itself with analysing static extensive matter, intuition for Bergson is the form of knowledge through which one follows an intensive movement. Beginning with his analysis of intuition in Bergsonism, Deleuze will rely upon this method of knowledge throughout his career. ${ }^{29}$ The current objective of this paper, however, is to emphasise how Bergsonian intuition requires depth for its explanation: intuition is precisely that which has depth, as opposed to (a) the instinct which is flattened intuition, ${ }^{30}$ and (b) the intellect which is cut out from intuition; ${ }^{31}$ Bergsonian intuition is that which moves from the depths of duration, as opposed to the intellect which serves to solidify the movements of intuition for static investigation; ${ }^{32}$ and finally, intuition is a selection mechanism capable of ensuring appropriateness to and for each organism by gauging the thickness or richness - in other words, depth - of an organism's "zone of indetermination." ${ }^{33}$ In each case, while it is always an extensive surface that offers itself up for analysis, this analysis is itself dependent upon an appropriate intuition that always occurs within (or more accurately comes forth from) the depths:

Let us then go down into our inner selves: the deeper the point we touch, the stronger will be the thrust which sends us back to the surface. Philosophical intuition is this contact, philosophy is this impetus. Brought back to the surface by an impulsion from the depth, we shall regain contact with science as our thought opens out and disperses. $^{34}$

Furthermore, insofar as this impetus from the depths to the surface concerns a proper duration rather than an extensive image of static time, it concerns a movement from the past to the present - the thickening of a present moment as it is stretched backwards. Thus the placing of ourselves into the intensive-depths is the placing of ourselves within the past as it moves towards the present, making a continuity or composite of the two (a whole duration). What defines this continuity is that it cannot be dissected into isolated parts without changing it in kind, for as soon as this is done, we are in the realm of surface extensities. This means that an historical trajectory from the past itself to the present, as opposed to those historical series which fully reside on the surface, cannot be cut and rearranged without changing 
its nature. If one is to appropriately understand the past as it moves to the present, one must therefore consider an entire duration in its depths, for as this depth changes so too will what is an appropriate understanding of it: "But the truth is that we shall never reach the past unless we frankly place ourselves within it." 35

The resonance of this last quote with the remarks of Braudel and Péguy mooted at the start of this paper could not be clearer. Let us then explore in more detail what their alternative form of history is. As mentioned, Braudel's ambition is to promote "a genuinely new form" of history. ${ }^{36}$ According to Braudel, the dominant practice and theory of history ignores and/or stifles life. In light of this: "It is precisely our task [as historians] to get beyond this first stage of history", in order that we can reach this other history capable of tackling social realities "in themselves and for themselves." ${ }^{37}$ Because it is this other form of history that is best suited to investigating life, Braudel proclaims: "As I have said before, it is life which is our school." ${ }^{38}$ Braudel even goes so far as to make the two synonymous: "Just like life itself, history seems to us to be a fleeting spectacle, always in movement, made up of a web of problems meshed inextricably together, and able to assume a hundred different and contradictory aspects in turn." ${ }^{39}$ By now it is obvious that for Braudel history need not be opposed to life, movement, contingency or becoming. The immediate question is: "How should one tackle such a complex, living entity?" ${ }^{40}$ Just as Bergson insists that the two forms of knowledge (intellect and intuition) demand their own respective methods of inquiry, so too Braudel notes that "each form of history demands an appropriate erudition." ${ }^{41}$ Furthermore, when prosecuting a Braudelian history, one must not reduce all and sundry to the one extensive time, but must rather be attuned to the various different durations involved. When one fails to do so,

This necessarily entails enormous errors of perspective and of reasoning, for what they are thus attempting to reconcile, to fit into the same framework, are in fact movements which have neither the same duration, nor the same direction, some belonging to the time of men, of our own brief, transient lives, others partaking of the time of societies, for whom a day, a year hold hardly any meaning, for whom, sometimes, a whole century lasts but a moment. Though we must of course be clear that social time does not flow at one even rate, but goes at a thousand different paces, swift or slow, which bear almost no relation to the day-to-day rhythm of a chronicle or of traditional history. 42

Braudel's insistence on the multiple nature of duration similarly holds for the complexity of history's schematisation: 
There is no unilateral history. No one thing is exclusively dominant: neither the conflict between races, whose collisions or reconciliation supposedly shaped the whole of man's past; nor powerful economic rhythms, creators of progress or ruin; nor constant social tensions; nor that diffused spiritualism that those like Ranke see as the sublimation of the individual and of the whole vast body of history; nor the reign of technology; nor the demographic expansion, that vegetable expansion with all its eventual consequences for the life of communities. Man's complexity is yet other. ${ }^{43}$

As to how this complexity can be appropriately approached, Braudel's answer is Bergson's: these different durations and complex histories are found "in the depths and most often in silence, whose domain, immense and uncertain as it is, we must now approach." 44

As a follower of Bergson, it is not surprising that Péguy will also share much with this approach. ${ }^{45}$ We have already seen how Péguy distinguishes between two ways of considering the event, one which consists in recording its effectuation in history and another which involves reassembling the event and installing oneself in it. Deleuze will rely on these heavily in order to oppose history and becoming. However, if we look beyond this oftquoted passage to the rest of Péguy's historical essays, we can see that what Péguy has in mind is an alternative historical method that does not merely trade in historical extensities on the surface but rather investigates historical events in depth. As Péguy writes, musing on what he would wish for instead of the litany of (republican) documents he consistently receives to be published in his journal Les Cahiers de la Quinzaine:

History will always tell us about the big chiefs, the leaders of history, more or less well, less rather than more, that's its métier; and if history does not, then historians will, and if historians do not then the professors (of history) will. What we want to know, and what we cannot invent, what we want to know more about, are not the principal roles, the leading stars, the grand drama, the stage, the spectacle; what we want to know is what went on behind, below, beneath the surface, what the people of France were like; in fact, what we want to know is the tissue of the people in that heroic age, the texture of the republican party. What we want to know is the texture, the very tissue of the bourgeoisie, of the Republic, of the people, when the bourgeoisie was great, when the people was great, when the republicans were heroic, and the Republic had clean hands. And to leave nothing unsaid, when Republicans were republicans, and the Republic was the republic. 
What we want is not a Sunday version of history, but the history of every day of the week, a people in the ordinary texture of its daily life; working and earning, working for its daily bread, panem quotidianum; a race in its reality, displayed in all its depth. ${ }^{46}$

Péguy's concern here is thus not with the facts of history per se, but with the culture that produces those facts. This may put him at odds with those forms of history that concern themselves with the analysis of historical extensities, but insofar as it does, it suggests to us another kind of historical technique and understanding - one that demands we become acquainted with a culture "displayed in all its depth" if we are to appropriately intimate its historical processes of production.

As it happens, exemplifying this alternative historical ontology and methodology was Péguy's original purpose for writing the essay the above passage is taken from. In 1907, Péguy was approached by the well-known Dreyfusard, Joseph Reinach, to write a history of the Dreyfus Affair. Declining to do so himself, Péguy in turn asked his friend Daniel Halévy to produce a historical account for his Cahiers. However, after publishing Halévy's account, titled Apology for Our Past, Péguy responded less than a year later with his own rival version, titled Memories of Youth (Notre Jeunesse). This was necessitated, Péguy believed, by the inability of Halévy's history to convey the appropriate spirit (mystique) of the Dreyfusard movement. Halévy most surely had many of the factual details correct, but what he failed to express was the life of the event - the vital and evolving forces that shaped the historical event and continued to be felt in the present. ${ }^{47}$ Memories of Youth was thus an attempt by Péguy to show how an alternative form of history is possible, one that is not disinterested and aloof but alive and continually creative. Moreover, in order to remain faithful to the historical event, to become worthy of the event, as Deleuze would say, ${ }^{48}$ Péguy sought to place himself back within its depths in order to feel its vibrancy and live its contingency. Péguy's history, as such, was not written from the privileged perspective of hindsight, replacing possibility with a retrospective historicism. Rather, it was expressed from within the depths of an historical movement that continues to speak to us today.

It should be noted that these thinkers of depth have not been called upon randomly. On the contrary, Braudel and Péguy are both specifically cited as the inspiration for Deleuze and Guattari's own alternative to traditional history. ${ }^{49}$ And to the extent that this alternative revolves around a theory of becoming that is predicated upon Bergson's notions of the virtual, multiplicity and duration, it is equally clear that Bergson's philosophy of historical depth is of great pertinence to Deleuze's. However, in recognising the affinity between Deleuze's understanding of depth - the pure spatium from which intensive production emerges - and the conceptions of depth in Bergson, Braudel and Péguy, the place and purpose of history in these 
accounts is called into question. Whereas depth for Bergson, Braudel and Péguy is in many respects a historical depth that is intensively productive in relation to the present and future, for Deleuze depth is a realm of becoming that is in turn overlaid by historical extensities. How then are we to explain this discrepancy?

It could be suggested that Deleuze repositions Bergson, Braudel and Péguy against history in order to emphasise the futural focus of his own philosophy. But while there is some truth to this, the case must not be overstated. Indeed, if the above historical thinkers can be said to have a common thread, it is precisely the great concern they all show for the future and the new. Given this, even if the bringing forth of the new is Deleuze's ultimate aim, the critical question remains: what role does history play in this process; what is the relation between the depths of the past and that which is yet to come?

In posing such a problematic, Deleuze's philosophy of space in the final chapter of Difference and Repetition is acutely reunited with his previous philosophy of time (from chapter two of Difference and Repetition). As he says:

We should not be surprised that the pure spatial syntheses here repeat the temporal syntheses previously specified: the explication of extensity rests upon the first synthesis, that of habit or the present; but the implication of depth rests upon the second synthesis, that of Memory and the past. Furthermore, in depth the proximity and simmering of the third synthesis make themselves felt, announcing the universal 'ungrounding'. Depth is like the famous geological line from NE to SW, the line which comes diagonally from the heart of things and distributes volcanoes: it unites a bubbling sensibility and a thought which 'rumbles in its crater'. Schelling said that depth is not added from without to length and breadth, but remains buried, like the sublime principle of the differend which creates them. ${ }^{50}$

What is most interesting about this alignment of the syntheses of space with the syntheses of time is that although this passage gestures to the third synthesis of the future - that which is beyond depth - Deleuze's interest here is more precisely with the way in which depth points towards the beyond. It is furthermore always in depth that the third synthesis makes itself felt. And finally, as Deleuze extrapolates when rounding off his discussion of intensive-depth: "The fact that they [intensities] cannot be added in any order whatsoever, or that they have an essential relation to an order of succession, refers us back to the synthesis of time which acts in depth." ${ }^{51}$ From this we can see that although depth is associated with the second synthesis 
of the past, both are not contrary to creation but an active participant in the process: "one does not hold without the other." 52

Accordingly, if the explanation of intensive-depth as an alternative form of history is significant, it is because it will address exactly how history can provide an opening towards the future, rather than a closure of it. Such a suggestion may betray the letter of Deleuze's theory, finding history where he placed becoming, but it is arguably more condusive to the kind of alternative to traditional history that Deleuze was seeking - an alternative history in line with Bergson, Braudel and Péguy that is intensive and capable of creation in concert with the present and future.

\section{Conclusion}

Throughout this paper I have explored the concepts of intensity and depth, as found in chapter 5 of Difference and Repetition and compared with the work of Bergson, Braudel and Péguy, in order to see what they might offer a Deleuzian philosophy of history. This project has been predicated upon the initial observation that Deleuze's hostility towards history is highly superficial: while it is true that Deleuze criticises history for its association with representation, explication, being and the actual, this is by no means the final word on history in Deleuze - it is only the first. Aside from this image of history-as-historicism, there is another history in the work of Deleuze, a history that draws its inspiration from the lineage of historical thinkers who themselves attempted to escape the dominant tradition. ${ }^{53}$ While it might be thought that Deleuze employs these thinkers to attack history in toto, this paper has shown how this negative construal can be replaced by a more positive project: namely, the affirmation of a creative philosophy of history.

History, in this respect, can be said to operate along two different axes. On the one hand, there are extensive histories: histories which order a series of extensive positions. These histories more or less resemble eulogies - a retrospective chronicle of a life. But, on the other hand, for each of these overlapping and encompassing historical series there is a correlate process of production. Each extensive series is the explication of a creative intensity; each one, as it were, has its own requisite depth or zone of intensity - that internal and novel story of genesis that is responsible for its identifiable distinction and differentiation from others. Insofar as "history matters" in the production and selection of each zone of intensity, history, as such, has a second axis, and this is found in the depths of intensity. This axis of history calls for a different kind of erudition, a method of intuition that allows us to follow an intensive movement along its progression from the depths to the surface.

By allowing for this distinction, history need no longer be opposed to becoming or the production of the new. Rather, history, as an intensive- 
depth, might be precisely that which enables an opening towards the future. Far from being a force of capture or domination (pouvoir), history might rather be an integral and active constituent in the process of creation (puissance), thus transforming the supposed opposition of history and becoming into a creative and differential composite. If this creative form of history is not immediately obvious in Deleuze's work, it is because it lies beneath the surface, in the depths of his thought. It is therefore imperative that we place ourselves within this historical thought, where it is actively working and producing.

1 Fernand Braudel, On History, trans. Sarah Matthews (Chicago: University of Chicago Press, 1980 [1969]), 10-11.

2 Gilles Deleuze and Félix Guattari, What Is Philosophy?, trans. Graham Burchell and Hugh Tomlinson (New York: Columbia University Press, 1994 [1991]), 111.

${ }^{3}$ Charles Péguy, Clio (Paris: Gallimard, 1931 [1909-12]), 266-9. For Deleuze's references to this passage, see: Gilles Deleuze, Difference and Repetition, trans. Paul Patton (London: Athlone Press, 1994 [1968]), 189; Gilles Deleuze, The Logic of Sense, trans. Mark Lester with Charles Stivale, ed. Constantin V. Boundas (London: Continuum, 1990 [1969]), 53; Gilles Deleuze, Negotiations: 1972-1990, trans. Martin Joughin (New York: Columbia University Press, 1995 [1990]), 170-1; and Deleuze and Guattari, What is Philosophy?, 111 and 157.

4 For more on Péguy's “mystique," see the essays in his Temporal and Eternal, trans. Alexander Dru (Indianapolis: Liberty Fund, 2001).

5 See Immanuel Kant, The Critique of Pure Reason (Radford, VA.: Wilder Publications, 2008 [1781]), 110-14.

${ }^{6}$ Deleuze, Difference and Repetition, 237 and 254.

${ }^{7}$ Deleuze, Difference and Repetition, 238.

${ }^{8}$ This stacking of difference produces Bergson's famous image of the cone. Although Bergson's cone is specifically a cone of memory, the image equally applies to the notion of virtual difference, as understood by Deleuze.

${ }^{9}$ It has been suggested by Keith Ansell Pearson that Deleuze criticises and indeed breaks with Bergson over the issue of intensity. See Keith Ansell Pearson, Germinal Life: The Difference and Repetition of Deleuze (London and New York: Routledge, 1999), 74. This is not entirely true. While the passage to which Ansell Pearson is referring most certainly begins with a criticism of Bergson, it is quickly retracted: "There comes a moment, however, in this philosophy of Difference which the whole of Bergsonism represents, when Bergson raises the question of the double genesis of quality and extensity. This fundamental differenciation (quality-extensity) can find its reason only in the great synthesis of Memory which allows all the degrees of difference to coexist as degrees of relaxation and contraction, and rediscovers at the heart of duration the implicated order of that intensity which had been denounced only provisionally and from without" (Deleuze, Difference and Repetition, 239, emphasis added). The footnote added further confirms that Deleuze's intention is not to 
depart from Bergson (on this issue) but if anything to show how Bergsonism can surmount this perceived problem: while duration and extensity, on the one hand, no doubt focus on the distinction between differences in kind and differences in degree, "in another manner duration is indistinguishable from the nature of difference and, as such, includes all the degrees of difference: hence the reintroduction of intensities within duration, and the idea of a coexistence in duration of all the degrees of relaxation and contraction (the essential thesis of Matter and Memory and La Pensée et le mouvant)" (Deleuze, Difference and Repetition, 331, note 14).

10 Deleuze, Difference and Repetition, 222.

${ }^{11}$ For a thorough investigation of Deleuze's three syntheses of time for a philosophy of history, see chapters 2-4 of Jay Lampert, Deleuze and Guattari's Philosophy of History (London and New York: Continuum, 2006).

12 See Deleuze and Guattari, What Is Philosophy?, 95.

13 Deleuze, Difference and Repetition, 222.

14 Deleuze, Difference and Repetition, 223; see 228. Also Gilles Deleuze, Desert Islands and Other Texts: 1953-1974, trans. Michael Taormina, ed. David Lapoujade (New York and Los Angeles: Semiotext(e), 2004 [2002]), 96.

15 Deleuze, Difference and Repetition, 230; see also 236-7.

${ }^{16}$ Deleuze, Difference and Repetition, 223.

17 Manuel DeLanda, "Space: Extensive and Intensive, Actual and Virtual," in Deleuze and Space, eds. Ian Buchanan and Gregg Lambert (Edinburgh: Edinburgh University Press, 2005), 82.

18 Deleuze, Negotiations, 170-1.

${ }^{19}$ Deleuze, Difference and Repetition, 186.

20 The reader should be reminded that Deleuze's analysis of intensity and depth occurs under the chapter title "Asymmetrical Synthesis of the Sensible."

21 See Henri Bergson, Creative Evolution, trans. Arthur Mitchell (Mineola, NY.: Dover Publications, 1998 [1907]), 39. See also page 91, which describes how radical finalism orders a series of static positions, shorn of all genuine movement (duration).

22 DeLanda, “Space: Extensive and Intensive, Actual and Virtual," 83 (emphasis added).

23 Deleuze, Difference and Repetition, 229.

24 Deleuze, Difference and Repetition, 229.

25 Deleuze, Difference and Repetition, 230.

26 Bergson, Time and Free Will, 113.

27 Bergson, Time and Free Will, 114.

${ }^{28}$ Henri Bergson, The Creative Mind: An Introduction to Metaphysics, trans. Mabelle L. Andison (Mineola, NY.: Dover Publications, 2007 [1934]), 106 (emphasis added).

${ }^{29}$ See for example Deleuze and Guattari, A Thousand Plateaus: Capitalism and Schizophrenia, trans. Brian Massumi (Minneapolis: University of Minnesota, 1989 [1980]), 409. See also Deleuze and Guattari, What Is Philosophy?, 40. 
30 Bergson, Creative Evolution, 182.

31 Bergson, Creative Evolution, 268.

32 Bergson, The Creative Mind, 18-19; see also 103-104.

33 Bergson, The Creative Mind, 19.

34 Bergson, The Creative Mind, 103. By "science", Bergson here means that form of knowledge which concerns itself with static extensities rather than genuine durations, i.e. the intellect rather than intuition.

35 Henri Bergson, Matter and Memory, trans. Nancy Margaret Paul and W. Scott Palmer (Mineola, NY.: Dover Publications, 2004 [1896]), 173.

${ }^{36}$ Braudel, On History, 18.

${ }^{37}$ Braudel, On History, 11.

38 Braudel, On History, 17.

${ }^{39}$ Braudel, On History, 10.

40 Braudel, On History, 10.

${ }^{41}$ Braudel, On History, 12.

${ }^{42}$ Braudel, On History, 12.

${ }^{43}$ Braudel, On History, 10.

${ }^{44}$ Braudel, On History, 10.

45 Péguy takes up many Bergsonian notions, such as duration and the cone of memory, no doubt learnt from his attendance of Bergson's lectures at the Collège de France.

46 Péguy, "Memories of Youth," in Temporal and Eternal, 4.

47 Alexander Dru, “Introduction,” in Péguy, Temporal and Eternal, xviii-xxvi.

${ }^{48}$ As Deleuze says in a remark quite reminiscent of Péguy: "Nothing more can be said, and no more has ever been said: to become worthy of what happens to us, and thus to will and release the event, to become the offspring of one's own events, and thereby to be reborn, to have one more birth, and to break with one's carnal birth - to become the offspring of one's events and not of one's actions, for the action is itself produced by the offsping of the event." See Deleuze, Logic of Sense, 149-50.

49 See Deleuze and Guattari, What is Philosophy?, 95-7 and 110-13. It could be noted that the other two thinkers cited in this passage - Nietzsche and Foucault - are also renowned for opposing the traditional understanding and methodology of history by offering their own alternative form of history.

50 Deleuze, Difference and Repetition, 230.

51 Deleuze, Difference and Repetition, 231 (emphasis added).

52 Deleuze, Difference and Repetition, 243.

53 Other examples could be added to this list, such as Nietzsche and Foucault. For an analysis of the relationtion between Nietzsche and Deleuze's untimely, see Craig Lundy, “Deleuze's 
Untimely: Uses and Abuses in the Appropriation of Nietzsche," in Deleuze and History, eds. Jeffrey A. Bell and Claire Colebrook (Edinburgh: Edinburgh University Press, 2009). Christian Kerslake has also shown in an excellent essay how Deleuze draws from the historian Arnold Toynbee for his concepts of nomadism and universal history. See Christian Kerslake, "Becoming against History: Deleuze, Toynbee and Vitalist Historiography," Parrhesia 4 (2008): 17-48. 